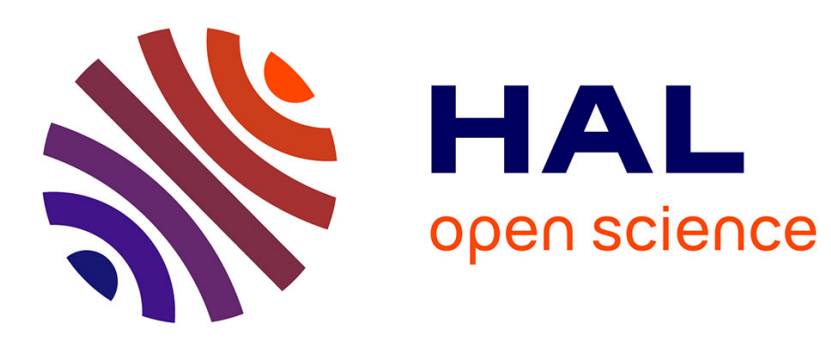

\title{
Factors affecting the successful cryopreservation of honey bee (Apis mellifera) spermatozoa
}

\author{
Brandon Kingsley Hopkins, Charles Herr
}

\section{To cite this version:}

Brandon Kingsley Hopkins, Charles Herr. Factors affecting the successful cryopreservation of honey bee (Apis mellifera) spermatozoa. Apidologie, 2010, 41 (5), 10.1051/apido/20010006 . hal-00892064

\section{HAL Id: hal-00892064 \\ https://hal.science/hal-00892064}

Submitted on 1 Jan 2010

HAL is a multi-disciplinary open access archive for the deposit and dissemination of scientific research documents, whether they are published or not. The documents may come from teaching and research institutions in France or abroad, or from public or private research centers.
L'archive ouverte pluridisciplinaire HAL, est destinée au dépôt et à la diffusion de documents scientifiques de niveau recherche, publiés ou non, émanant des établissements d'enseignement et de recherche français ou étrangers, des laboratoires publics ou privés. 


\title{
Factors affecting the successful cryopreservation of honey bee (Apis mellifera) spermatozoa*
}

\author{
Brandon Kingsley HoPkINS, Charles HeRR \\ Center for Animals Near Biological Extinction, 1016 S. Main Colfax,WA 99111, USA \\ Received 14 April 2009 - Revised 19 November 2009 - Accepted 24 November 2009
}

\begin{abstract}
This report is about cryopreservation of honey bee semen. There has been little advancement of this technology over the past 20 years. Cytotoxicity of the cryoprotectants, temperature sensitivity, freezing rate, and cold shock were investigated. The least toxic cryoprotectant was DMSO. Spermatozoa were tolerant to temperatures up to $40{ }^{\circ} \mathrm{C}$. A programmable freezing rate of $3{ }^{\circ} \mathrm{C} /$ min proved superior in most treatments when compared to a freezing rate of approximately $28000{ }^{\circ} \mathrm{C} / \mathrm{min}$. Highest viability of spermatozoa (93\%) post cryopreservation resulted from the treatment containing a $10 \%$ DMSO diluent, slow cooled to just above freezing, and frozen at a rate of $3{ }^{\circ} \mathrm{C} / \mathrm{min}$. Spermatozoa frozen in such a manner yielded viability and motility indistinguishable from that of unfrozen semen. Promising results warrant a field study.
\end{abstract}

cryopreservation / Apis mellifera / spermatozoa / cold shock / vitrification

\section{INTRODUCTION}

There is a need for honey bee semen cryopreservation to counter allelic losses caused by the population declines due to Varroa mites, colony collapse disorder, and other future threats. Maximum storage life at room temperature for honey bee semen is approximately two weeks (Cobey, 2007). Liquid nitrogen $\left(\mathrm{LN}_{2}\right)$ storage of spermatozoa promises long-term storage capabilities; but success with $\mathrm{LN}_{2}$ storage methodologies are currently inadequate for use in instrumental insemination because of poor brood production (Melnichenko and Vavilov, 1976; Harbo, 1979, 1983; Verma, 1983; Kaftanoglu and Peng, 1984). Kaftanoglu and Peng (1984) reported using cryopreserved semen for instrumental insemination and achieved $47 \%$ worker production; lower than the ideal 95-99\%, indicating a low fertilization rate. It has been

Corresponding author: B.K. Hopkins, kingsley27@msn.com

* Manuscript editor: Yves Le Conte decades since the last reported study, meaning methods have been shelved for years.

Our research project investigated honey bee spermatozoa cryopreservation by studying factors that might reasonably have affected post-thaw viability. These factors included the type and concentration of cryoprotectant, the effect of cold shock, freezing rates, and general temperature sensitivities. Cryoprotectants are molecules that prevent intracellular ice; ice being the primary damaging agent (Watson and Fuller, 2001). Cold shock is the term used when cells are damaged by too quickly cooling to temperatures just above freezing (Kaftanoglu and Peng, 1984). The cells of some species need to be cooled slowly to just above freezing, whereas the cells of other species can be cooled quickly without injury. This study investigated two freezing rates, programmable freezing and rapid freezing. The rapid freezing method was an attempt to achieve a vitrified amorphous state of water. Programmable freezing is a technique where samples are cooled slowly and ice is encouraged to form outside the cells, effectively dehydrating cells and preventing intracellular 
ice (Mazur, 1963). In contrast, vitrification is an attempt to cool so fast ice crystals have no time to form either inside or outside cells; the minimum cooling rate has been estimated to be $30000{ }^{\circ} \mathrm{C} / \mathrm{min}$. This minimum rate though depends on cryoprotectant type and concentration (Risco et al., 2007). In order to accomplish this rate, samples must be tiny and have a sufficiently high surface area to volume ratio. The small volume of semen produced by honey bees made it an attractive candidate for the vitrification approach.

\section{MATERIALS AND METHODS}

\subsection{Semen collection}

Honey bee semen was kindly collected for us by Susan Cobey, UC, Davis using methods similar to those described by Laidlaw (1977). Semen was collected from multiple drones using a Harbo's syringe (Harbo, 1985). After collection, the semen was held until use in a glass capillary tube sealed with petroleum and stored at room temperature. Spermatozoa were verified viable prior to use in treatments, using the staining procedure described in Section 2.9.

\subsection{Diluents}

We tested five different diluents each containing one of three different cell -permeating cryoprotectants. All solutions were made using water purified to $18.6 \mathrm{meg}$-ohms. Semen was mixed 3:2, semen to diluent, except in the case of the modified ram semen diluent as described below.

The first diluent was prepared with $500 \mu \mathrm{L}$ buffer, $250 \mu \mathrm{L}$ dimethyl sulfoxide (DMSO) (ICN, Cat\# 191418), and $250 \mu \mathrm{L}$ egg yolk. The buffer was made by adding $239 \mathrm{mg} \mathrm{NaH} \mathrm{PO}_{4}$ (Sigma, Cat\# S7907) and $112 \mathrm{mg} \mathrm{Na}_{2} \mathrm{HPO}_{4}$ (Sigma, Cat\# S-8282) to make a final volume of $25 \mathrm{~mL}$ and $\mathrm{pH}$ adjusting to 7.2 with $6 \mathrm{M} \mathrm{NaOH}$ (Harbo, 1983). This diluent, referred to herein as Harbo's diluent, was one of two used in the preliminary experiment and also subsequently in the other experiments.

The buffer is presented here in final concentrations prior to mixing with cryoprotectant, egg yolk and semen (pH adjusted to 7.2 using $\mathrm{NaOH}$ ) contained:

\section{- $79.7 \mathrm{mM} \mathrm{NaH}{ }_{2} \mathrm{PO}_{4}$}

- $31.6 \mathrm{mM} \mathrm{Na}_{2} \mathrm{HPO}_{4}$

The second diluent, used only in the preliminary experiment, was a modification of one used for ram semen (Evans and Maxwell, 1987); the modification being the increased glycerol concentration from $4.5 \%$ to $9 \%(\mathrm{v} / \mathrm{v})$. Modified glycerol diluent (Mod. Gly.) was prepared by adding $1.91 \mathrm{~g}$ of tris(hydroxymethyl)aminomethane (Tris Base) (Invitrogen, Cat\# 15504-020), $263 \mathrm{mg}$ glucose (Sigma, G-8270), 958 mg citric acid (Sigma, Cat\# C-2404), $2.96 \mathrm{~mL}$ glycerol (BDH, Cat\# 101186M), 32,895 IU penicillin (Sigma, Cat\# P-4687), $33 \mathrm{mg}$ streptomycin (Sigma, Cat\# S-1277), filled to a final volume of $25 \mathrm{~mL}$. The addition of $24 \%$ egg yolk was mixed fresh on the day prior to mixing with semen. Semen was mixed with diluent in a 1:1 ratio.

Our Mod. Gly. is presented here in final concentrations prior to mixing with semen or egg yolk $(\mathrm{pH}$ adjusted to 7.2 using $6 \mathrm{M} \mathrm{NaOH}$ ).

- $630.7 \mathrm{mM}$ Tris Base

- $58.4 \mathrm{mM}$ glucose

- $199.5 \mathrm{mM}$ citric acid

- $11.8 \%$ glycerol (v/v)

The following four diluents used in this experiment contain the same base solution composed of: $6.08 \mathrm{~g}$ trehalose (Sigma, Cat\# T-9531), $268 \mathrm{mg}$ glucose, $268 \mathrm{mg}$ fructose (Baker, Cat\# M556-05), $879 \mathrm{mg}$ citric acid, $1.662 \mathrm{~g}$ Tris Base, plus the addition of one of four cryoprotectants (Tab. I), and filled to a final volume of $25 \mathrm{~mL}$. The addition of $30 \%$ egg yolk was mixed fresh on the day prior to mixing with semen. Semen and diluents were mixed at a ratio of $3: 2$, respectively.

The HH DMSO, HH Extra DMSO, HH Glycerol and Ethylene glycol (EG) diluents are presented here as concentrations prior to mixing with semen or egg yolk ( $\mathrm{pH}$ adjusted to 7.2 using $6 \mathrm{M} \mathrm{NaOH}$ ).

- $709.2 \mathrm{mM}$ Trehalose

- $59.5 \mathrm{mM}$ Glucose

- $59.5 \mathrm{mM}$ Fructose

- 183.0 mM Citric Acid

- 548.8 mM Tris Base

Final cryoprotectant concentrations including egg yolk and semen for HH Glycerol, HH DMSO, HH Extra DMSO, and EG are: $8 \%$ glycerol, $10 \%$ DMSO, 15\% DMSO, and $3.7 \%$ ethylene glycol, respectively. 
Table I. Treatments with respective total cell counts from pooled samples and percentage of viable cells listed in descending order of cell viability. Different letters in the \% viable column indicate a significant difference $(P<0.002)$. Vit=vitrified freezing, Pro=programmable freezing, slow vs. rapid cool is treatment of sample prior to freezing.

\begin{tabular}{lcc}
\hline Treatment & Total cell counts & $\%$ Viable (+/-) SD \\
\hline Pro/Slow cool/Harbo's & 1403 & $92.94+/-0.87(\mathrm{~A})$ \\
Vit/Slow cool/Harbo's & 626 & $77.48+/-1.67(\mathrm{~B})$ \\
Vit/Rapid cool/Harbo's & 538 & $75.46+/-1.86(\mathrm{~B})$ \\
Vit/Rapid cool/HH DMSO & 755 & $52.85+/-1.82(\mathrm{C})$ \\
Pro/Rapid cool/HH DMSO & 345 & $48.41+/-2.67(\mathrm{D})$ \\
Vit/Slow cool/HH DMSO & 748 & $47.06+/-1.78(\mathrm{E})$ \\
Vit/Slow cool/Extra DMSO & 1202 & $42.68+/-1.41(\mathrm{E})$ \\
Vit/Rapid cool/Extra DMSO & 721 & $42.44+/-1.86(\mathrm{E})$ \\
Pro/Slow cool/Extra DMSO & 1160 & $36.12+/-1.38(\mathrm{~F})$ \\
Vit/Slow cool/EG & 839 & $27.29+/-1.54(\mathrm{G})$ \\
Pro/Slow cool/HH DMSO & 566 & $24.56+/-2.34(\mathrm{G})$ \\
Pro/Rapid cool/EG & 507 & $22.29+/-2.07(\mathrm{G})$ \\
Pro/Slow cool/EG & 896 & $14.29+/-1.19(\mathrm{H})$ \\
Pro/Rapid cool/Harbo's & 425 & $13.41+/-1.71(\mathrm{H})$ \\
Vit/Rapid cool/EG & 492 & $2.44+/-0.68(\mathrm{I})$ \\
\hline
\end{tabular}

${ }^{1} \mathrm{SD}$ is an abbreviation for standard deviation.

\subsection{Freezing containers}

Semen was frozen in micro glass cryostraws, fabricated by pulling Pasteur pipettes (VWR, cat\# 14672-380) to an internal diameter of approximately $150-180 \mu \mathrm{m}$. Size of the straws was determined using an ocular micrometer. Fluid is moved in and out of the straws by fitting a short piece of Silastic ${ }^{\circledR}$ tubing (0.062" ID; 0.095" OD; Dow Corning cat\# 602-265) over the end of the straw. All straws were siliconized by drawing up and expelling Sigmacote (Sigma, Cat\# SL-2) and then left to cure overnight. Straws siliconized to reduce residual loss and aid in drawing and expelling semen.

\subsection{Mixing semen and diluent}

Semen was mixed with the diluents by drawing samples from the capillary tube containing semen using a pulled capillary tube, siliconized (same as above), and fitted to a Hamilton threadedplunger syringe (Model \#1001TPLT) backfilled with Fluorinert ${ }^{\circledR}$ (Electronic Liquid FC-77, Cat\# 98-0204-0701-5). Fluorinert ${ }^{\circledR}$ was ideal because of its non-toxicity, low viscosity and insolubility in aqueous solutions. These properties allowed for easy and accurate control while moving semen. Volumes were controlled using the threaded syringe calibrations $(1 / 4$ turn $=3.25 \mu \mathrm{L})$. Semen samples and diluents were mixed in separate wells of a Robinson Scientific Low Profile Terasaki 96 well tray (cat\# 1007-01-0). Straws were loaded with $3 \mu \mathrm{L}$ of semen/diluent.

\subsection{Cooling samples prior to freezing}

Samples from each treatment were cooled from room temperature to $\sim 0{ }^{\circ} \mathrm{C}$ by one of two methods prior to freezing. (1) Slow cooled samples loaded in micro glass cryostraws were sheathed in $0.5 \mathrm{~mL}$ Cassou Straws (IMV, France) and submerged in $450 \mathrm{~mL}$ of room temperature water in a $600 \mathrm{~mL}$ beaker and placed in a standard refrigerator for two hours, which is when the water became $\sim 4{ }^{\circ} \mathrm{C}$. After two hours in the refrigerator, samples were removed from the Cassou Straws and plunged into an ice water bath for $4 \mathrm{~s}$, bringing the samples to $\sim 0{ }^{\circ} \mathrm{C}$. (2) Rapidly cooled samples were removed from the Cassou Straws at room temperature just before freezing and plunged in to an ice water bath for $4 \mathrm{~s}$. 
Immediately after submergence in the ice bath, all samples were either placed back into the Cassou straw, and then placed in a programmable freezing chamber, or plunged, without a sheath into a $\mathrm{LN}_{2}$ vortex.

\subsection{Vitrification}

Three styrofoam coolers were placed side-byside. The first was a round container placed on a magnetic stirrer (Fisher Sci. Jumbo Stirrer) with a magnetic stir bar on the bottom. Stirring the $\mathrm{LN}_{2}$ at the highest setting created a vortex that maximized the cooling rate by rapidly removing any vapor formed around the sample as it froze (Stucky et al., 2008). Micro glass cryostraws were removed from their sheaths plunged into the ice bath, held for $4 \mathrm{sec}$ and then plunged into the outer edge of the $\mathrm{LN}_{2}$ vortex for $15 \mathrm{~s}$. Samples were then rapidly moved from the vortex container into the second $\mathrm{LN}_{2}$ container in order to be re-sheathed under $\mathrm{LN}_{2}$. The sheathed samples were then transferred in $\mathrm{LN}_{2}$ into a third $\mathrm{LN}_{2}$ container so they could be packed into the $\mathrm{LN}_{2}$ storage goblet. The goblets were then transferred to a standard $\mathrm{LN}_{2}$ tank and maintained under $\mathrm{LN}_{2}$ at atmospheric pressure ranges of our local.

\subsection{Programmable freezing}

Micro glass cryostraws were loaded into their Cassou sheaths after being submerged in the ice water bath, and loaded into the Freeze Control Cryochamber (CL-3000 CryoLogic PL, Australia), holding at $0{ }^{\circ} \mathrm{C}$. Controlled freezing of all samples was done at a rate of $3{ }^{\circ} \mathrm{C} / \mathrm{min}$ from $\sim 0{ }^{\circ} \mathrm{C}$ to $-40{ }^{\circ} \mathrm{C}$. When the temperature reached $-40{ }^{\circ} \mathrm{C}$ the samples were removed from the cryochamber and plunged into $\mathrm{LN}_{2}$ where they were packed into a goblet for storage.

\subsection{Thawing}

We froze spermatozoa using two substantially different freezing rates; consequently, we used two different thawing methods to coincide with the freezing method. Currently accepted thought is that the risk of ice damage to cells also occurs during the thawing process. Vitrified samples need to be rapidly thawed (Rall and Fahy, 1985). Micro glass cryostraws frozen in the $\mathrm{LN}_{2}$ vortex were thawed rapidly. Each was removed from its sheath and $\mathrm{LN}_{2}$, simultaneously, and plunged for $3 \mathrm{~s}$ into a $37^{\circ} \mathrm{C}$ circulating water bath (VWR, model 1167).

The micro glass cryostraws that were frozen using the programmable freezing unit were air thawed. A hair dryer was fixed to a post and a distance was found at which the air coming from the unit was $\sim 40{ }^{\circ} \mathrm{C}$. Each micro glass cryostraw was removed from its sheath and $\mathrm{LN}_{2}$, simultaneously, and held at the position providing $40{ }^{\circ} \mathrm{C}$ air for $7 \mathrm{~s}$.

\subsection{Live/dead cell staining for cell viability}

Spermatozoa were stained using a dual fluorescent nucleic acid staining system (Molecular Probes cat\# L7011, Eugene, OR) (Collins and Donoghue, 1999). The live stain (SYBR-14) was diluted 1:10 in DMSO. Samples were expelled from their micro glass cryostraws into $1.5 \mathrm{~mL}$ Ependorff tubes containing $1 \mu \mathrm{L}$ of the diluted SYBR-14 (live stain) and $1 \mu \mathrm{L}$ of propidium iodide (dead stain), and $98 \mu \mathrm{L}$ of Earls balanced salt solution. Spermatozoa were then incubated at $37{ }^{\circ} \mathrm{C}$ for $6 \mathrm{~min}$. Viablity rates were evaluated based on live/dead cell counts. Cells staining red were counted dead, cells staining green were counted alive. Samples were observed in $1 \mu \mathrm{L}$ drops on an inverted epifluorescent microscope with a xenon light source and required filters.

The few described motility observations were made using an inverted microscope at 320X magnification with phase contrast. Motility was observed as undulating tails after dilution in Earls balanced salt solution including the live/dead cell stain. Motility was noted as either present or absent.

\section{EXPERIMENTAL DESIGN}

\subsection{Preliminary experiment}

A preliminary cryopreservation study was conducted to investigate the possibility of vitrification for honey bee semen. Harbo's (1983) diluent and a controlled freezing rate of $3{ }^{\circ} \mathrm{C} / \mathrm{min}$ was used for comparison. Along with the two different freezing rates, two diluents were tested: "Harbo's diluent" and "modified glycerol diluent" as described above. Semen was frozen and thawed on two separate 
occasions. All samples in this experiment received the slow cooling treatment. The first attempt was thawed after storage in $\mathrm{LN}_{2}$ for 343 days. The second was thawed after 6 days. All samples were stained and counted using the same method. There were not multiple samples within the treatments.

\subsection{Cryoprotectant toxicity}

In order to investigate the toxicity of the different diluents independent of the freezing and thawing, semen was mixed with each diluent and left to equilibrate for one hour. At one hour, samples were examined for motility; then stained, and subjective live/dead cell counts were performed. Toxicity in this study is defined as the degree to which cryoprotective diluents caused cell death. The one-hour time point was chosen as an estimated room temperature handling time of semen in diluent during the cryopreservation process.

\subsection{Temperature sensitivity}

To generate useful information for thawing purposes, an experiment was run to determine the highest temperature honey bee spermatozoa could tolerate without causing measurable damage. Four water baths were set up in separate styrofoam containers: $30,35,40$, and $45^{\circ} \mathrm{C}$. A micro glass cryostraws was taped to the side of each of the containers with the semen/diluent submerged. The straws were left in their relative water baths for 1 hour, and then the spermatozoa within were stained for live/dead cell counts.

\subsection{Cryopreservation}

\subsubsection{Cold shock}

Two out of every five micro glass cryostraws per diluent treatment were left at room temperature until plunging into an ice water bath immediately prior to freezing. This lowered sample temperature from room temperature to $0{ }^{\circ} \mathrm{C}$ within $1 \mathrm{~s}$. These treatments were performed to test the effects of cold shock. The other three out of five samples were treated with the slow cooling procedure explained above.

\subsubsection{Freezing rate}

Five (2 rapid cooled, 3 slow cooled) of every 10 samples for each diluent were frozen using the programmable freezing unit. The other 5 were frozen in the $\mathrm{LN}_{2}$ vortex.

\subsubsection{Diluents}

For each of the four diluents used in the main cryopreservation experiments, 10 straws were loaded with the diluent semen mixture. Half the straws for each of the diluents were frozen in the programmable freezing unit, and the other half were frozen in the $\mathrm{LN}_{2}$ vortex.

\subsection{Statistical analysis}

Analysis of post-thaw viability ratios involved the large-sample statistical test for estimating differences between binomial parameters of two binomial populations (Mendenhall, 1979). The $\mathrm{z}$ statistics calculated according to Mendenhall formed the basis for a twotailed test for significant difference between the proportions of viable cells measured for each treatment. In the cryopreservation study replicates within each treatment yielded similar results that were not statistically different, therefore the results of the replicates were pooled for statistical analysis between treatments.

\section{RESULTS}

\subsection{Preliminary experiment}

For the experiment in which samples were stored in $\mathrm{LN}_{2}$ for 6 days the greatest proportion of viable cells $(93.2 \%)$ received vitrification freezing, slow cooling to above $0{ }^{\circ} \mathrm{C}$ and were in Harbo's diluent. The proportions of viable cells in the remaining treatments ranked as follows: programmable freezing, 
slow cooling in Harbo's (78.8\%); vitrification, slow cooling, with $\mathrm{HH}$ glycerol (38.9\%); and, programmable freezing, slow cooling with $\mathrm{HH}$ glycerol $(26.0 \%)$. Comparisons of viability of spermatozoa between treatments differed significantly $(P<0.002)$.

For the experiment in which samples were stored in $\mathrm{LN}_{2}$ for 343 days the greatest proportion of viable spermatozoa as determined by live/dead cell stain $(54.26 \%)$ received programmable freezing, slow cooling, and Harbo's diluent. The proportions of viable cells in the remaining treatments ranked as follows: vitrified freezing, slow cooling with Harbo's diluent (41.46\%); vitrification, slow cooling with glycerol (18.77\%); and, programmable freezing, slow cooling with glycerol $(6.52 \%)$.

\subsection{Cryoprotectant toxicity}

Motility was maintained and $95 \%$ of the spermatozoa remained viable after an hour at room temperature in both Harbo's and $\mathrm{HH}$ DMSO diluents. Spermatozoa motility was absent in both glycerol and EG containing diluents. Upon dilution of the samples containing EG motility resumed, and $90 \%$ of the sperm cells were viable. Spermatozoa in the glycerol diluent never resumed motility, and staining revealed cell viability of just $35 \%$. Only $65 \%$ of spermatozoa stained alive after an hour when mixed with the HH Extra DMSO diluent.

\subsection{Temperature sensitivity}

Figure 1 shows the viability of spermatozoa after submerging samples in water baths at $30,35,40$, and $45^{\circ} \mathrm{C}$ for 1 hour. Samples exposed to temperatures of 30,35 , and $40{ }^{\circ} \mathrm{C}$ showed no significant reduction in viability after 1 hour. The sample exposed to the $45^{\circ} \mathrm{C}$ water bath showed a substantial decrease in viability after exposure for 1 hour (Fig. 1).

\subsection{Cryopreservation}

Slow cooling samples prior to programmable freezing using Harbo's diluent resulted in sperm cell viability of $93 \%$, and

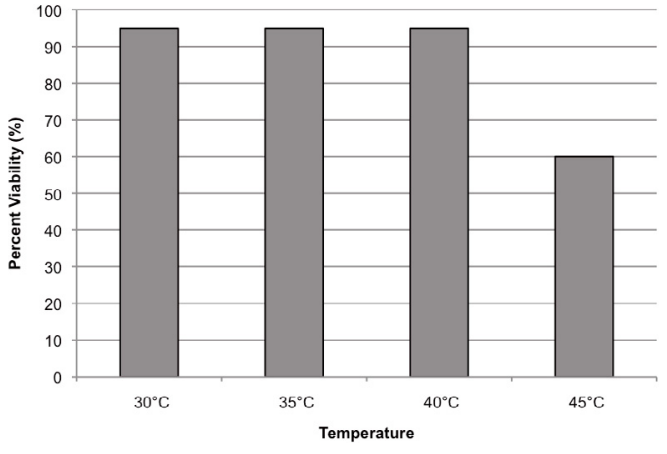

Figure 1. Cell viability calculated as (\# viable cells)/(total \# cells) using dual fluorescent staining system after exposure to different temperatures for $1 \mathrm{~h}$.

was significantly different than all other treatments $(P<0.002)$ (Tab. I). In a side-by-side comparison with fresh semen motility was indistinguishable. Motility was absent in all other treatments. Rapidly cooling spermatozoa to just above $0{ }^{\circ} \mathrm{C}$ prior to freezing and then programmable freezing in Harbo's diluent resulted in $13.41 \%$ viability (Tab. I).

A method was considered successful if viability was above $50 \%$. Four methods provided a satisfactory viability by this measure: programmable freezing/slow cooling/Harbo's diluent (92.94\%); vitrified/slow cooling/Harbo's diluent $(77.48 \%)$; vitrified/rapid cooling/Harbo's diluent (75.46\%); and, vitrified/rapid cooling/HH DMSO $(52.85 \%)$.

No samples in the ethylene glycol diluents produced greater than $30 \%$ viability. Samples in HH Extra DMSO treatment did not produce viability above $43 \%$ (Tab. I).

\section{DISCUSSION}

Using Harbo's diluent, slow cooling to prevent cold shock, and freezing samples at $3{ }^{\circ} \mathrm{C} / \mathrm{min}$ produced the greatest spermatozoa viability $(93 \%)$ (Tab. I). Motility in this treatment was indistinguishable from unfrozen semen. When using the same diluent and freezing rate, but rapidly cooling to just above $0{ }^{\circ} \mathrm{C}$ the viability of spermatozoa was just $13 \%$, and motility was absent. Comparing these two 
results would suggest that honey bee spermatozoa is susceptible to cold shock when frozen at $3{ }^{\circ} \mathrm{C} / \mathrm{min}$ in Harbo's diluent. When Harbo (1983) performed his freezing experiments, spermatozoa containing solutions were loaded as $22 \mu \mathrm{L}$ volumes in capillary tubes and placed in a refrigerator at $5{ }^{\circ} \mathrm{C}$ overnight. The cooling rate would be expected to have been more rapid than our slow cooling method and might explain his lower percentage of worker brood $(22 \%)$. Harbo provided no post-thaw cell viability data that would make possible a comparison with our study. Whereas these results are consistent with honey bee spermatozoa being cold shock sensitive, interestingly, cold shock did not appear to be as important a factor with the other treatments (Tab. I). The other treatments being resistant to cold shock would be consistant with findings in Kaftanoglu and Peng's (1984) report. Harbo's diluent is the only one that lacked Tris base. We observed that at least a portion of the egg yolk in Harbo's diluent formed an insoluble flocculent, whereas, in diluents containing Tris base, the egg yolk and diluent appeared clear, as if the yolk had been solubilized. It has been suggested that egg yolk protects against the effects of cold shock (Amann and Graham, 1993). Maybe the difference in egg yolk solubility is why slow cooling to above $0{ }^{\circ} \mathrm{C}$ was such a major factor in Harbo's diluent and not in others. Hopefully, slow cooling might eliminate the need for egg yolk, or make finding a replacement easier, which is one of our future goals.

In the preliminary experiments, viability was poor in treatments using glycerol. Cryoprotectant toxicity tests, using live/dead staining, were done in order to investigate cell viability independent of the effects of freezing and thawing. We found that the glycerol containing diluent caused the greatest percentage of cell death prior to freezing; interesting because glycerol is widely and successfully used for mammalian semen freezing (Curry, 2007). Glycerol was eliminated as a candidate cryoprotectant in this study. However, cryoprotectant toxicity of glycerol was not tested prior to our preliminary experiments and so was used. The lower spermatozoa viability recorded in the glycerol containing treatments in the pre- liminary experiments might have been in part caused by the glycerol toxicity, not freezing. A future study is needed that includes a treatment where glycerol is added to the Harbo's base diluent.

Ethylene glycol was far less toxic to spermatozoa than glycerol, but simple observations of motility could have easily concealed this fact. When placed in a diluent containing EG, all motility ceased. However, when diluted out of the diluent, motility was restored. An interesting possibility seemed that maybe spermatozoa might benefit by having motility inhibited during the freezing process. No results bared this out though. In general, EG performed poorly as a honey bee semen cryoprotectant. However, a future study is needed that includes a treatment where EG is added to the Harbo's base diluent.

Spermatozoa survived well and seem to tolerate both "HH DMSO diluent" and "Harbo's DMSO diluent" absent freezing. To further investigate the limits of tolerance to DMSO, spermatozoa were exposed to an even greater concentration of DMSO in our "HH DMSO diluent" ("HH Extra DMSO") in order to determine the cells' toxicity limit. At the increased concentrations of DMSO $(15 \% \mathrm{v} / \mathrm{v})$, there was a significant drop in cellular viability over an hour at room temperature.

We tested two different freezing rates: $3{ }^{\circ} \mathrm{C} / \mathrm{min}$ and rapid freezing (vitrification). Future studies that test other freezing rates and methods would seem worthwhile. It would be worth testing some more commonly used freezing methods used in the artificial breeding industry. Freezing in pellets on dry ice and in $\mathrm{LN}_{2}$ vapor are some of the industry standards for semen freezing. However, it would seem more worthwhile to first field test the method that generated the best results presented within this report, since these results appeared to equal unfrozen semen in terms of viability and motility. Our current concern is for the compatibility of the diluent with queen insemination. Harbo (1976) reported queens produced normal progeny when inseminated with semen containing DMSO at concentrations below $12 \%$. However, egg yolk has not been tested in the insemination of queens. 
The tiny volume of semen collected from a drone made it an attractive candidate for the vitrification method. This being the first reported study of honey bee semen vitrification, the method could be improved by reducing the number of transfers between $\mathrm{LN}_{2}$ baths. In preliminary experiments, vitrification showed promising results, but samples thawed after prolonged storage had significantly lower cell viability. Using the same method of freezing and thawing; samples stored for 6, 42, and 343 days resulted in $93.2,77.5$, and $41.5 \%$ viability, respectively. Although these comparisons are of data from different experiments, and the experiments were not designed to investigate this unexpected phenomenon; still this decline in post-thaw spermatozoa viability when using the vitrification method warrants concern. Searching the literature revealed a recent study published on cryopreservation of mouse embryos that reported similar findings (Mozdarani and Moradi, 2007). The study included a vitrification treatment where the severity of damage and subsequent failure of embryos was related to the amount of time spent in $\mathrm{LN}_{2}$ storage. Ice crystals forming at $\mathrm{LN}_{2}$ temperatures in the storage straws over time might be the cause of the decline in cellular viability for vitrified samples. This finding would contradict a currently accepted concept within the field of cryobiology, which is that below a temperature called the glass transition temperature; ice fails to form (Giovambattista et al., 2004). We are further researching this phenomenon.

Results using the method of slow cooling semen in Harbo's diluent, and freezing in a programmable freezing unit are promising enough to warrant field trials. Live/dead cell staining is useful but limited in its ability to assay sperm viability. Obviously, the point of the technology is to use it in the field. Next, use of the cryopreserved semen with the instrumental insemination of queens is necessary.

There is an urgent need for the cryopreservation of honey bee spermatozoa. The frightening losses of honey bees and humans' vital link to the species means the ability to properly preserve and distribute honey bee genetics is now crucial. Increased genetic diversity has been shown to decrease severity of infection
(Seeley and Tarpy, 2007), and enhance productivity and fitness (Mattila and Seeley, 2007). There are populations of bees that do not require chemical treatment for the control of parasites or disease because of genetic characteristics. With proper cryopreservation methods those valuable alleles can be stored in the form of semen, analyzed and distributed worldwide for the purpose of increasing genetic diversity and selective breeding without fretting time constraints or environmental conditions. Certainly, there are yet to be discovered important alleles, which might disappear in the future without a conscious effort at preserving the currently available genetic diversity.

\section{ACKNOWLEDGEMENTS}

We would like to thank Susan Cobey for providing the semen for this project. Walter S. Sheppard for his assistance. Phillip Baker for his support in preparation of lab equipment.

Facteurs jouant un rôle dans le succès de la cryopréservation de spermatozoïdes de l'abeille Apis mellifera.

cryopréservation / Apis mellifera / spermatozoïdes / stress thermique / froid / vitrification

Zusammenfassung - Faktoren, die die erfolgreiche Kältekonservierung von Spermatozoen der Honigbiene (Apis mellifera) beeinflussen. Honigbienen können instrumentell besamt werden (I.B.). Das Potential der I.B. wird jedoch dadurch begrenzt, dass es unmöglich ist, den Samen über längere Zeiträume hinweg aufzubewahren. Da Einfrieren nicht möglich ist, muss aufgenommener Samen innerhalb von kurzer Zeit verbraucht werden. Geeignete Verfahren der Kältekonservierung würden jedoch die wiederholte Nutzung einer umfassenden Sammlung von Sperma während einer Saison, oder ihre Aufbewahrung zur Konservierung wertvoller genetischer Ressourcen erlauben.

Einflüsse, die möglicherweise die Lebensfähigkeit der Spermien nach dem Auftauen beeinflussen könnten, wurden untersucht. Ein Review ergab vier allgemeine Faktoren, auf die wir unsere Arbeit konzentrierten: (1) Zelltoxizität von Kälteschutzmitteln, (2) Temperaturempfindlichkeit von Spermien, (3) die Gefrierrate, und (4) Kälteschock. Samen wurde aufgenommen und vor dem Gebrauch für 7 Tage in einer Glaskapillare aufbewahrt. Der Samen wurde im Verhältnis von drei zu zwei mit verschiedenen Verdünnern gemischt. Die Zellgiftigkeit von Kälteschutzmitteln wurde 
getestet, indem der Samen mit Verdünner gemischt wurde, der Kälteschutzmittel enthielt, und dann für eine Stunde in Glaskapillaren aufbewahrt wurde. Das Überleben der Zellen wurde in der gesamten Studie durch eine Lebend-Tot-Fluoreszenzfärbung gemessen. Mit Lösungsmitteln, die 10 \% DMSO enthielten, blieb die Beweglichkeit erhalten und $95 \%$ der Spermatozoen überlebten. Wenn das Lösungsmittel jedoch $15 \%$ DMSO enthielt, blieben nur $65 \%$ der Spermazellen am Leben. Die Beweglichkeit der Spermatozoen ging deutlich zurück, wenn die Lösungsmittel Glyzerin oder EG enthielten; die Färbung ergab, dass in diesen Fällen $35 \%$ bzw. $90 \%$ der Zellen überlebten.

Die Temperaturempfindlichkeit wurde gemessen, indem Glaskapillaren mit der Samen/Lösungsmittelmischung für eine Stunde in verschieden temperierte Wassserbäder getaucht wurden. Proben, die Temperaturen von $30{ }^{\circ} \mathrm{C}$, $35^{\circ} \mathrm{C}$, und $40{ }^{\circ} \mathrm{C}$ ausgesetzt wurden, zeigten keine signifikante Reduktion der Lebensfähigkeit. Die Probe, die einer Temperatur von $45{ }^{\circ} \mathrm{C}$ ausgesetzt wurde, zeigte dagegen einen deutlichen Rückgang der Lebensfähigkeit (Abb. 1).

Die Experimente zur Kryokonservierung wurden so angelegt, dass sechs verschiedene Kälteschutzmittel, zwei Gefrierraten und der Effekt von Kälteschock in einem kombinierten Ansatz untersucht werden konnten. Die Kombination von Faktoren, die zur größten Überlebensfähigkeit (93\%) beitrugen, war: Harbo's Verdünnung mit $10 \%$ DMSO, bei langsamer Abkühlung und Einfrieren in einem programmierbaren Gefriergerät bei $3{ }^{\circ} \mathrm{C} / \mathrm{min}$ (Tab. I).

Die mit der Methode des langsamen Abkühlens von Samen in Harbo's Verdünnung und Einfrieren in einem programmierbaren Gefriergerät erzielten Ergebnisse sind vielversprechend genug für Feldstudien. Offensichtlich liegt der Nutzen der Technologie in der Anwendbarkeit in der Praxis.

\section{Kältekonservierung / Apis mellifera / Spermato- zoen / Kälteschock / Vitrifizierung}

\section{REFERENCES}

Amann R.P., Graham J.K. (1993) Spermatozoal Function, in: McKinnon A.O., Voss J.L. (Eds.), Equine Reproduction, Blackwell Publishing, pp. $715-745$.

Cobey S.W. (2007) Comparison studies of instrumentally inseminated and naturally mated honey bee queens and factors affecting their performance, Apidologie 38, 390-410.

Collins A.M., Donoghue A.M. (1999) Viability assessment of honey bee (Apis mellifera) sperm using dual fluorescent staining, Theriogenology 51, 1513-1523.

Curry M.R. (2007) Cryopreservation of mammalian semen, in: Day J.G., Stacey G.N. (Eds.),
Cryopreservation and Freeze-Drying Protocols, Second Edition, Humana Press, pp. 303-311.

Evans G., Maxwell W.M.C. (1987) Salamon's Artificial Insemination of Sheep and Goats, Butterworths, Australia, pp. 122-141.

Giovambattista N., Angell C.A., Sciortino F., Stanley H.E. (2004) Glass-transition temperature of water: A simulation study, Phys. Rev. Lett. 93, 047801-1047801-4.

Harbo J.R. (1976) Survival of honey bee spermatozoa in Liquid Nitrogen, Ann. Entomol. Soc. Am. 70, 257-258.

Harbo J.R. (1979) Storage of honey bee spermatozoa at $-196^{\circ} \mathrm{C}$, J. Apic. Res. $18,57-63$.

Harbo J.R. (1983) Survival of honey bee (Hymenoptera: Apidae) spermatozoa after two years in liquid nitrogen $\left(-196{ }^{\circ} \mathrm{C}\right)$, Ann. Entomol. Soc. Am. 76, 890-891.

Harbo J.R. (1985) Instrumental insemination of queen bees - Parts 1 \& 2, Am. Bee J. 125, 197-202, 282 287.

Kaftanoglu O., Peng Y. (1984) Preservation of honeybee spermatozoa in liquid nitrogen, J. Apic. Res. 23, 157-163.

Laidlaw H.H. Jr. (1977) Instrumental insemination of honey bee queens: pictoral instruction manual, Hamilton, IL: Dadant \& Son.

Mattila H.R., Seeley T.D. (2007) Genetic diversity in honey bee colonies enhances productivity and fitness, Science 317, 362-364.

Mazur P. (1963) Kinetics of water loss from cells at subzero temperatures and the likelihood of intracellular freezing, J. Gen. Physiol. 47, 347-369.

Melnichenko A.N., Vavilov Y.L. (1976) Long term storage of drone semen by freezing in liquid nitrogen SP S Kennan, Soviet Agric. Sci. 1, 34-36.

Mendenhall W. (1979) Introduction to Probability and Statistics, in: Beal C. (Ed.), 5th ed., Duxbury Press, Belmont, CA.

Mozdarani H., Moradi S.Z. (2007) Effect of vitrification on viability and chromosome abnormalities in 8-cell mouse embryos at various storage durations, Biol. Res. 40, 299-306.

Rall W.F., Fahy G.M. (1985) Ice-free cryopreservation of mouse embryos at $-196^{\circ} \mathrm{C}$ by vitrification, Nature 133, 573-575.

Risco R., Elmoazzen H., Doughty M., He X., Toner M. (2007) Thermal performance of quartz capillaries for vitrification, Cryobiology 55, 222-229.

Seeley T.D., Tarpy D.R. (2007) Queen promiscuity lowers disease within honeybee colonies, Proc. R. Soc. Lond. B Biol. Sci. 274, 67-72.

Stucky M., Hopkins B.K., Herr C. (2008) Cryopreservation of honey bee spermatozoa, Reprod. Fert. Dev. 20, 127-128.

Verma L.R. (1983) Effect of deep freezing on the survival of the honey bee (Apis mellifera L.) spermatozoa, Am. Bee J. 123, 851-852.

Watson P.F., Fuller B.J. (2001) Principles of Cryopreservation of Gametes and Embryos, in: Watson P.F., Holt W.V. (Eds.), Cryobanking The Genetic Resource: Wildlife Conservation for the Future? CRC Press, London, pp. 21-46. 